\title{
The City Of Aba And Goal 11 Of The United Nations Sustainable Development Goals (SDGs): An Examination
}

\author{
Ogadimma R.Iroka *, Chiedozie P. Nwosu ${ }^{* *}$, Babatunde M. Idowu ${ }^{* * *}$, Felix M. Nwankwo ${ }^{* * * * *}$ \\ * Social Mobilization Consultant PoPCare Project, Center for Communication and Social Impact House 2, 16B P.O.W Mafemi Crescent, Utako, \\ Abuja Nigeria \\ ** Department of Political Science, Faculty of Social Sciences Alex-Ekwueme Federal University, Ndufu-Alike Ikwo (AE-FUNAI) PMB 1010 \\ Abakaliki, Ebonyi State, Nigeri \\ ${ }^{* * *}$ Department of Criminology \& Security Studies, Faculty of Social Sciences Alex-Ekwueme Federal University, Ndufu-Alike Ikwo (AE-FUNAI) \\ PMB 1010 Abakaliki, Ebonyi State, Nigeria \\ ***** Department of Political Science, Faculty of Social Sciences, Alex-Ekwueme Federal University, Ndufu-Alike Ikwo (AE-FUNAI) \\ PMB 1010 Abakaliki, Ebonyi State, Nigeria
}

DOI: 10.29322/IJSRP.11.09.2021.p11723

http://dx.doi.org/10.29322/IJSRP.11.09.2021.p11723

\begin{abstract}
This paper examines the Goal 11 of the United Nations Sustainable Development Goals (SDGs) and the city of Aba in Abia State, South East Nigeria - in terms of how the city has fared, the prospects as well as the challenges it faces in meeting up with this goal. Despite being one of the commercial nerve centres in Nigeria, the city has over the years, been characterised by poor urban development - as it has been existing spontaneously without proper urban management and planning. The paper adopted the new urban sociology perspective and globalization as theoretical frameworks and strongly recommends for strong political will policy continuity and consistency on the part of the government, social mobilization of the people to change their poor urban development attitude, promotion and standardization of made in Aba products - to boost the local market within and beyond, among others.
\end{abstract}

Index Terms- Development, SDGs, SDGs goal 11, United Nations, City of Aba.

\section{INTRODUCTION}

$\mathrm{T}$ he year 2007 marks the year when, for the first time in the history of humanity, half of the world's population will be living in cities. Urban populations are expected to increase by 1.5 billion over the next 20 years, while the number of megacities will double. By 2015 the UN predicts that there will be 358 "million cities" with one million or more people and 27 "mega-cities" with ten million or more. Much of this growth will happen in developing countries. The scale and pace of urbanization is opening up unforeseen possibilities. Large concentrations of people and goods provide increased opportunities for creativity, larger labour markets, and higher levels of productivity, not to speak of the cultural and political opportunities associated with urban life. Urban explosion also poses daunting challenges. It can result in unemployment and insufficient investment in basic services with the resulting environmental and social problems (International Congress on Human Development, Madrid, 2006). As stated above, developing countries which Nigeria is one of them, are not left out in this wave of urbanization and the prospects and problems that come with it. According to Okike in Ezeani and Nnanta (2000:77), "urbanization in developing countries including Nigeria is closely associated with economic, social and administrative problems. In Nigeria, specifically, the following problems are discernable:(a) Population explosion, (b) inadequacy of social services provision, (c) unemployment and increased social vices, (d) environmental problems of various ramifications and magnitude, (e) inadequate housing, (f) planlessness with attendant urban sprawl, (g) health problem, (h) illiteracy, (i) uncoordinated development/poor articulated urban policies as a result of fragmented urban political authority, (j) government poor attitude on urban and regional planning, (k) poverty and(l) inability to maintain existing facilities." Similarly and most recently, Nations Human Settlements Programme, UN-Habitat 2016 world city report, has it that, about 80 million Nigerians are living in slums. Slums and informal settlements in Nigeria are as a result of rapid urbanization, which brings in its wake challenges of supply of adequate land, decent housing and other services that make settlements prosper, healthy and liveable (UN-Habitat Participating Slum Upgrading Porgramme, 2016). Alarmingly, even the city of Abuja, the Nigeria's capital, is not spared from the problem of urban slum. According to Omeje (2017), apart from the Central Business Area and Wuse, it was discovered that every other district in the capital city has sordid slums that present an ugly picture of Abuja, which was once thought to be the fastest growing capital city in Africa.

In the same vein, the city of Aba, which is the focus of this paper, is affected bythese urban problems. Located in Abia State, South East Nigeria, Aba is a cluster of five local government areas. Unfortunately, in terms of urban development and improvement, the city is associated with the hereunder highlighted urban problems in Nigeria - despite the economic activities and growth in the city over the years. According to the office of the senior special assistant to theAbia State Governor on SDGs (2016), urbanization problems in the city of Aba, include the following:

1. Decayed infrastructure that was created from colonial administrators over a century ago;

2. Absence of city-wide or metropolitan-wide governance structure; 
3. Rising poverty as exemplified in the formation of slums and ramshackle housing and business structures that are unplanned, uncontrolled, congested, filthy and polluted;

4. Traffic congestion and associated air pollution due to poor roads and inadequate transport management;

5. Non-existence of physical development plans or City Development Strategies;

6. Non-adoption of participatory land use planning and development;

7. Inadequate provision for essential urban basic services and incessant flooding.

However, with the necessary political attention and participatory urban development management and planning mechanisms, the city of Aba has the potentials to tap the prospects in urbanization and achieve significant improvement. It is against this backdrop that this paper attempts to look at the prospects and challenges of urban development of the city in line with the Goal11 of the United Nation's Sustainable Development Goals.

\section{ClarificAtion OF CONCEPTS}

\section{United Nation's Sustainable Development Goals (Goal 11 in Perspective)}

In September 2015 Heads of States and Governments agreed to set the world on a path towards sustainable development through the adoption of the 2030 Agenda for Sustainable Development. This agenda includes 17 Sustainable Development Goals, or SDGs, which set out quantitative objectives across the social, economic, and environmental dimensions of sustainable development - all to be achieved by 2030 . The goals provide a framework for shared action "for people, planet and prosperity," to be implemented by "all countries and all stakeholders, acting in collaborative partnership." As articulated in the 2030 Agenda, "never before have world leaders pledged common action and endeavour across such a broad and universal policy agenda." 169 targets accompany the 17 goals and set out quantitative and qualitative objectives for the next 15 years. These targets are "global in nature and universally applicable, taking into account different national realities, capacities and levels of development and respecting national policies and priorities (Sustainable Development Solutions Network, 2015).Among the 17 goals of the SDGs is Goal11, which emphasises onmaking cities and human settlements inclusive, safe, resilient and sustainable. The specific targets of the goal are as follows.

1. By 2030, ensure access for all to adequate, safe and affordable housing and basic services and upgrade slums

2. By 2030, provide access to safe, affordable, accessible and sustainable transport systems for all, improving road safety, notably by expanding public transport, with special attention to the needs of those in vulnerable situations, women, children, persons with disabilities and older persons

3. By 2030, enhance inclusive and sustainable urbanization and capacity for participatory, integrated and sustainable human settlement planning and management in all countries

4. Strengthen efforts to protect and safeguard the world's cultural and natural heritage
5 By 2030, significantly reduce the number of deaths and the number of people affected and decrease by $[\mathrm{x}]$ per cent the economic losses relative to gross domestic product caused by disasters, including water-related disasters, with a focus on protecting the poor and people in vulnerable situations

6. By 2030, reduce the adverse per capita environmental impact of cities, including by paying special attention to air quality and municipal and other waste management

7 By 2030, provide universal access to safe, inclusive and accessible, green and public spaces, in particular for women and children, older persons and persons with disabilities

7a. Support positive economic, social and environmental links between urban, peri-urban andrural areas by strengthening national and regional development planning

$7 \mathrm{~b}$. By 2020, increase by [x] per cent the number of cities and human settlements adopting and implementing integrated policies and plans towards inclusion, resource efficiency, mitigation and adaptation to climate change, resilience to disasters, develop and implement, in line with the forthcoming Hyogo Framework, holistic disaster risk management at all levels

7c.Support least developed countries, including through financial and technical assistance, in building sustainable and resilient buildings utilizing local materials (Open Working Group proposal for Sustainable Development Goals, 2015).

Looking at the SDGs goal 11 and its specific target, and the city of Aba urban development problems, one would think that the city was one of the cities the UN had in mind when formulating the goal, as the need for goal in the city, is clearly obvious.

\section{Demography and Brief Bio of the City of Aba}

The city of Aba is domiciled in Abia State, South Eastern Nigeria between latitude $5.07^{\circ} \mathrm{N} 7.22^{\circ} \mathrm{SE}$ and longitude $5.177^{\circ} \mathrm{N}$ $7.367^{\circ} \mathrm{E}$ (Ukpong, Udo\& Umoh,2015) Although variations exist as to the exact population of the city but the 2006 Census by the National Population Commission gave 936, 821 as the exact population. This is with the summation of the four Local Governments that make up the city- Obingwa, Aba North, Aba South and Osisioma (NPC, 2006).It is a major city in the southeast of Nigeria and the commercial nerve centre of eastern Nigeria (Izugbara and Umoh, 2004). According to Munro (1995), the city of Aba was set up by the Ngwa stock of Igbo people of Nigeria first as a market town and later a military post was instituted there by the British colonial government in 1901.Hoiberg (2010) opines that the city lies along the west bank of the Aba River at the intersection of roads from Port Harcourt, Owerri, Umuahia, IkotEkpene, and IkotAbasi (Opobo). The city has its major economic contributions in the areas of textiles and palm oil, along with pharmaceuticals, plastics, cement, and cosmetics (Munro, 1995). There are well known markets in Aba such as the Ariaria International Market, AhiaOhuru (New Market), Eziukwu Road Market (Cemetery Market), Shopping Centre (Ekeoha), etc that serve the entire region with quality wares, provisions, cosmetics, among others.

The city, dubbed 'The Japan of Africa' as it is one of the industrial and commercial nerve centres in Nigeria - as such, provides sources of income for individuals, corporate entities, the State and Local governments. As far back as 1922, the city has been on the map historically with the famous Aba women riot during the colonial era in Nigeria (Falola\& Heaton, 2008). Citing 
a study presented by Professor OkechukwuAnyamele,(a Professor of Economics and Finance, at Jackson State University, in the United States), at Aba urban renewal summit, Nkuma (2016) gave a summary of urban population and economy of the city of Aba as follows:

- Between 2000 and 2015, Aba's economy grew at an annual rate of $7.44 \%$.

- In 2000, Aba’s GDP stood at $\$ 1.57$ billion; by 2015 , it had grown to $\$ 4.9$ billion.

- In 2014, Gross National Income per capita of Nigeria was $\$ 2,760$

- $\quad$ Aba's GDP with official population of 917,355 will put Aba's income per capita at $\$ 9,778$.

- Aba's income per capita in 2014 was 3.5 times that of Nigeria.

- An analysis of the data based on current US\$, indicates a bigger economy of Aba capable of sustaining Abia State, if well managed.

- The household consumption of Aba in 2015 $\$ 4,828,301,225$.

- Given the official household population of 269,727 translates into $\$ 17,901$ per household and per capita consumption of $(\$ 4,828,301,225 / 944,045)$.

\section{THEORETICAL REVIEW}

There are two contending perspectives to the study of urbanization - the Western liberal or Modernization perspective and Marxist perspective. Each of these perspectives provides an explanation for growth and social effects of urbanism. Under the Marxist perspective, there are theoretical strands - which include the new urban sociology and the theory of peripheral urbanization (Ezeani in Ezeani and Nnanta (2000). For the purpose of this paper, the new urban sociology is adopted as a theoretical framework. The paper also adopts, or perherps 'borrow' globalization theoretical perspective to look the effects of globalization on economic growth of the city of Aba and how it affects urban development of the city.

\section{THE NEW URBAN SOCIOLOGY}

According to Ezeani in (Ezeani and Nnanta, 2000), the new urban sociology owns so much to works of Castells (1978), Gordon (1978), Harvey (1973), Lojkine (1976), Pickvance (1976), Merrington (1975) and many other scholars. Baldassare (1983:2930) cited by Ezeani in Ezeani and Nnanta (2000:8), captured the main position of these scholars as follows:

The organization of urban life is determined by the forces that have power in our society. All decisions are guided by capitalist attempts to achieve greater wealth and advantage against competitors. The "political-economic" force that determine urban shape and form emanate from multinational corporation, local, national, and regional firms, and individuals capitalists. The world system of cities, national urban networks, metropolitan exchange, intra-city activities, and resident groups' welfare are all subject to the political economy influence.
The new urban sociologists also contend that there are political struggle within the cities that account for specific urban reforms. Of particular interest is the role of land speculation in influencing the type of housing development, transportation system and resident that are found in a particular area (Feagin, 1980). The role of the state was also closely scrutinized through the Marxist perspective. Successive American governments are seen as agents of capitalism, making policies that benefit industries and land owners (Mollenkofpf, 1978). The class character of city planning was also emphasized by the new urban sociologists who see city planning as concentrating on the mediation of capitalist conflict and the promotion of profit-making rather representing public interests (Castells, 1978). The "new" urban sociologists, contend that any analysis that ignores the political-economic realm espouses conservative ideology regarding the causes and salient consequences of urban phenomena (Castells, 1976).

With this theoretical background, in the case of the city of Aba and in light of the SDG Goal 11, this paper contends that:

- Lack of urban development and improvement in the city, is as result of government and business owners view of the city, as a city, for just commercial activities - where corporate entities, traders, artisans and individuals do business to make profit and pay revenue to the government;

- Economic activities and growth alone cannot lead to quality urbanization in the sense of development, without corresponding political attention and intervention that would mobilize relevant stakeholders (including the people - the city residents) for participatory urban development management and planning.

Accordingly, the above arguments, could account for why the city of Aba, despite dubbed 'Japan of Africa' with all the industrial and commercial activities going on in the city over the years, has remained one of the worst cities in Nigeria. For instance, according to the office of the senior special assistant to the State Governor on SDGs (2016), it was under the then state government, that Aba urban renewal agency - for the city development, management and planning, was established. The state government is also,in collaboration with UN Habitat, producing functional master plan documents for Aba and two other cities; strengthening institutional capacities/processes of Abia State Ministries, Departments and Agencies and key actors in local participatory planning to manage and guide urban development in a sustainable way; improving access to serviced land, administration of land and local economic development; and has held the first Aba Urban Development Summit - a summit of key stakeholders which involved discussions on vital priorities for Aba, and the creation of a road map for its development, and mobilization of resources. Previously, the city has been spontaneously existing without proper urban management and planning, and was devoid of participatory engagement of the people (businesses and residents) on the need to steer the city towards development. 


\section{Globalization Perspective}

According to Okereke and Ekpe (2000:171) citing Aina (1996), "globalization refers to the process of making "'global," "being present worldwide," at world stage", or "global arena.", Dauda (2001) also cited in Okereke and Ekpe (2000:171) observes that "an issue, object(s), institution(s), or practice is global if through commerce, production, consumption, politics and the information technology it is visible or considered relevant in global centres." Dauda (ibid) further points out that globalization "entails universalization whereby object, practices or even values transcend geo-political boundaries, penetrate the hitherto sovereign nation-state and impacting the orientation and value system of the people.",

Globalization theoretical perspective as applied in this paper is simply used to look at the effect of global movement of goods and services on the urban economy of the city of Aba. The city is known for garment and shoe making - which in calculation, would account for a reasonable percentage of the city's GDP. But with the influx of other global fashion brands - even fashion product from China, Turkey etc, as a result of globalization, Aba products in Nigeria face stiff competition for market share. This (global) competition shrinks the local market size of made in Aba products and by implication, reduces the city's earning with attendant negative impact on its economy. It is based on this, that the current state government is leading the 'Made in Aba' campaign as part of the 'Made in Nigeria' campaign and pursuing standardization of the city's product for international market share. This initiative is expected to increase the city's earning and generate more employment and contribute towards SDGs goal 11 in the city.

\section{The City of Aba and the Prospects and Challenges of Achieving SDGs Goal 11}

\section{Prospects of Achieving SDGs Goal 11 by the City of Aba}

The prospects are discussed under three major themes- Political, industry and commerce.

(a) Political - the current state government

- has established Aba urban renewal agency - for the city development, management and planning;

- in collaboration with UN Habitat, is producing functional master plan documents for Aba and two other cities;

- $\quad$ is strengthening institutional capacities/processes of Abia State Ministries, Departments and Agencies and key actors in local participatory planning to manage and guide urban development in a sustainable way;

- $\quad$ is improving access to serviced land, administration of land and local economic development;

- has held the first Aba Urban Development Summit - a summit of key stakeholders which involved discussion on vital priorities for Aba, and the creation of a road map for its development, and mobilize resources.

(b) Industry

- Aba has the biggest concentration of SMEs in Africa

- Thriving leather \& garment industry

- Championing of "Made in Nigeria" products that can be expanded to the global market with emphasis on quality standardization

(c) Commerce

- A logistics hub for the South East \& South-South bounded by 7 states with access to the sea
- Aba \& environs' is the commercial nerve centre for the south-east, south-south, West \& Central African regions

- Development Plan: Proposed Dredging of Aba River to the Atlantic (about $50 \mathrm{NM}$ ) will be akin to the wonder created by St. Lawrence Sea Way.

\section{Challenges of Achieving SDGs Goal 11 by the City of Aba}

As has been argued in the theoretical framework, the challenges facing urban development of the city of Aba in tandem with the SDGs goal 11, are as follows:

1. Political will, policy continuity and consistency;

2. Poor urban development attitude among the people;

3. Negative effect of globalization on local market share of made Aba products.

\section{DISCUSSION OF FINDINGS}

The foregoing reveals how much the city of Aba, given its location, availability of large markets, industrial clusters, can be poised to attain Goal 11 of the UN Sustainable Development Goals. This is informed by the fact that the city has all it takes to become a major industrial and economic hub and indeed a mega city in Nigeria. It must be stated however that, despite the fact that the city has promising prospects of attaining these goals, there are daunting challenges that could prevent it. These challenges must be nipped in the bud if Aba is to have a pride of place in the committee of mega cities in the world.

Findings from the study also revealed that succeeding governments in Abia state, where Aba is located, have paid lip service towards the development of the city. This is not encouraging as the city, even in its squalid nature, generates lots of income to the state.

The residents of the city have also contributed their own quota towards de-beautifying its landscape. As posited by (Ukpong et al.,2015) A large amount of solid waste generated in Aba municipality are dumped on roads, water ways, dumpsites that are unapproved, drainages,etc. indiscriminately and this negatively affects the outlook of the city and damages the environment.

\section{CONCLUSION}

The paper has taken a thorough look at the city of Aba, its demography, prospects as well as challenges towards recording significant urban developmentand improvement in keeping with the SDGs Goal11. Results of the findings reveal that the city has got a lot on its plate if it is to become a mega city by 2050. All hands therefore must be on deck for this to be a reality. The government must make concerted efforts, backed with good political will, to urbanise the city. The, residents of the city must also play their own role to ensure that government's effort are not nipped in the bud.

\section{RECOMMENDATIONS/ POLICY OPTIONS}

On the strengthof the findings uncovered in this paper,these recommendations are considered germane towards ensuring that the city of Aba attains Goal 11 of the SDG's. 
1. The current government and future administrations should show enough political will - continue to improve and sustain the current Aba urban development political interventions;

2. There is need for social mobilization of business owners, traders, artisan and resident of the city, for them to change perception and attitude of the city and promote and participate in its urban development;

3. The 'Made in Aba' and the products standardization campaigns can never be over emphasised - as the effort will go a long way in expanding the market for Aba products - and by implication, improving its economy which will contribute towards SDGs goal 11 in the city.

4. there must be strong political will - policy continuity and consistency on the part of the government; there is also need for social mobilization of the people to change their poor urban development attitude and support and participate in the city's development; and the need for the promotion and standardization of made in Aba products - to boost the local market within and beyond.

5. The Abia state government should use her state orientation agency to create awareness to Aba residents of how to properly conduct themselves in cities especially in the area of waste disposal as this is one of the areas that de-beautify the city and negatively impact on the environment.

6. There is the urgent need for the promotion and standardization of made in Aba products as this will ultimatelygenerate export earnings to the country, add to the GDP and put the city in its proper place economically.

\section{REFERENCES}

[1] Aina, T. A. (1996) "Globalization and Social Policy in Africa," Research Network CODERISA Bulletin

[2] Duada A. (2001) "Globalization Social Sciences, and Nigeria in 211st Century " in Newsletter of Social Science Academy of Nigeria, vol. 4 No. 1, March.

[3] Baldassare, M. (1983) "Introduction: Urban Changes and Community" In Baldassare, M. (Ed) Cities and Urban Living. New York: Columbaia University Press.

[4] Castells, M. (1978) The Urban Question. Boston: M.I.T Press.

[5] Castells, M. (1976) "Theory and Ideology in Urban Sociology" In C.G. Pickvance, (Ed) Urban Sociology: Critical Essays, New York: St. Martins.

[6] Ezeani, E O. \&Nnanta N E. (2000). Issues in Urbanization and Urban Admnistration in Nigeria, Enugu: Jamoe Enterprise (Nigeria).

[7] Ezeani, E O. (2000) 'Contending Theoretical Perspective on Global Urbanization" In Ezeani, E O. \&Nnanta N E. (Ed) Issues in Urbanization and Urban Admnistration in Nigeria, Enugu: Jamoe Enterprise (Nigeria).

[8] Gordon (1978) "Capitalist Development and the history of American Cites"In Williams, K. Tabb andLarry Sawyers (Ed) Marxism and the Metropolos: New Perspectives in Urban Political Economy. New York: Oxford University Press.

[9] Falola, T \& Heaton M.,(2008). A History of Nigeria. Cambridge, UK: Cambridge University Press. ISBN 978-0-521-68157-5.

[10] Feagin, I. (1980) "Unrban Real Estate Speculation" A Presented at the American Sociological Association Meeting, New York.

[11] Freire Mila (2006) "Urban planning: challenges in developing countries" Presented at the International Congress on Human Development, Madrid.

[12] Harvey, D (1973) Social Justice and the City. Baltimore: John Hopkins University Press.

[13] Hoiberg D. (2010) 'Abia '.Encyclopedia Britanica.1 ( 15th ed.). Chicago: EncyclopediaBritanica Inc. Pp32. ISBN 978-1-59339-837-8.
[14] Izugbara, C.O and Umoh, J.O (2004). "Indigenous Waste Management Practices among the Ngwa of Southeastern Nigeria: Some Lessons and Policy Implications". The Enviromentalist. 24(2):87-92.doi: 10.1007/s10669-0044799-4

[15] Lojkine, J. (1976) "Contributions to A Marxist Theory of Capitalist Urbanization" In C.G. Pickvance, (Ed) Urban Sociology: Critical Essays, New York: St. Martins.

[16] Pickvance (1976) Urban Sociology: Critical Essays, New York: St. Martins.

[17] Merrington, J.(1975) "Town and Country in the Transition to Capitalism" New York Left Review, 93.

[18] Mollenkopf, J. (1978) “The Post-war Politics of Urban Development" In Williams, K. Tabb and Larry Sawyers (Ed) Marxism and the Metropolos: New Perspectives in Urban Political Economy. New York: Oxford University Press.

[19] Munro, D (1995) “Aba'. The Oxford Dictionary of the World. Oxford, UK Oxford University Press. ISBN 0-19-866184-3.

[20] National Population Commision (2006) PHC Priority Table. Available from http://population.gov.ng/core-activities/surveys/dataset/2006-phc-prioritytables/: Retrieved 20/04/2020.

[21] Nkuma, Ikechukwu (2016) “Why Aba Summit?Why Not?” In Premium Time Nigeria newspaper; Available at www.pmnewsnigeria.com

[22] Office of the Senior Special Assistant to Abia State Governor on SDGs (2016) 'Perspectives from Aba."' Presented by Chime Asonye, JD., Senior Special Assistant to Abia State Governor on SDGs, at Common Wealth Local Government Forum, Accra Ghana.

[23] Okereke O.O \&Ekpe A. E. (2000) Development and Underdevelopment: Politics of the North-South Divide. Enugu: John Jacob's Classic PublishingLtd.

[24] Omeje,Chikezie (2017)“Abuja In the Midst Of Slums - The Story Of A Fast Decaying City"International Centre for Investigative Reporting. Available at icirnigeria.org

[25] Participatory Slum Upgrading Porgramme (2016) Slum Almanac 2015/2016 Tracking Improvement in the Lives of Slum Dwellers,UN Habitat, Nairobi. Available at www.worldurbancampaign.org

[26] Sustainable Development Solutions Network (2015).Getting Started with the Sustainable Development Goals: A Guide for Stakeholders.

[27] Ukong ECU, Udo EA, Umoh IC (2015) Characterization of Materials from Aba Waste Dumpsites. Int.JEng Applied Sci.

[28] UNDOCS (2015).Open Working Group proposal for Sustainable Development Goals. Available at http://undocs.org/A/68/970

\section{AUTHORS}

First Author - Ogadimma R.Iroka, Social Mobilization Consultant PoPCare Project, Center for Communication and Social Impact House 2, 16B P.O.W Mafemi Crescent, Utako, Abuja Nigeria Tel: +2347064658382 . E-

Mail:ogadinmairoka@gmail.com

Second Author - Chiedozie P. Nwosu, Department of Political Science, Faculty of Social Sciences, Alex-Ekwueme Federal University, Ndufu-Alike Ikwo (AE-FUNAI), PMB 1010 Abakaliki, Ebonyi State, Nigeria; Tel: +2348039584367, E-mail: chiedozienwosu@gmail.com; chiedozie.nwosu@ funai.edu.ng Third Author - Babatunde M. Idowu, Department of Criminology \& Security Studies, Faculty of Social Sciences, Alex-Ekwueme Federal University, Ndufu-Alike Ikwo (AEFUNAI), PMB 1010 Abakaliki, Ebonyi State, Nigeria; Tel: +2347067684330, E-mail: mitbabss@ gmail.com;

babatunde.idowu@funai.edu.ng

Fourth Author - Felix M. Nwankwo, Department of Political Science, Faculty of Social Sciences, Alex-Ekwueme Federal University, Ndufu-Alike Ikwo (AE-FUNAI), PMB 1010 Abakaliki, Ebonyi State, Nigeria; Tel: +2348033606390, Email:felixnwankwo2@gmail.com 
International Journal of Scientific and Research Publications, Volume 11, Issue 9, September 2021

This publication is licensed under Creative Commons Attribution CC BY. 